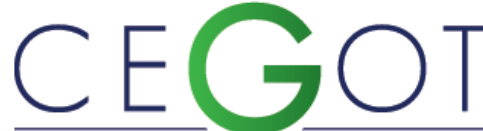

Centro de Estudos de Geografia e Ordenamento do Território
Prefeitura Municipal de Cascavel (Setor de Regularização Fundiária) 85.810-011, Cascavel, Brasil (Rua Paraná, n 5.000, Centro) karensolek@yahoo.com.br

\section{CORDOVIL, FABÍOLA}

Universidade Estadual de Maringá (Depart. de Arquitetura e Urbanismo) 87.020-900, Maringá, Brasil (Av. Colombo, ${ }^{\circ} 5.790$, Bloco 32, Centro Tecnologia, Zona 7) cordovilfabiola@gmail.com

\title{
A Fronteira de Expansão do Capital como Condicionante para a Produção da Irregularidade Urbana: Análise Multiescalar da Atuação da Companhia de Habitação de Cascavel, Paraná, Brasil
}

The frontier of expansion of capital as conditioning for the production of urban irregularity: multiscale analysis of the performance of the Housing Company of Cascavel, Paraná, Brazil

Referência: Soares, Karen; Cordovil, Fabíola (2019).A Fronteira de Expansão do Capital como Condicionante para a Produção da Irregularidade Urbana: Análise Multiescalar da Atuação da Companhia de Habitação de Cascavel, Paraná, Brasil. Revista de Geografia e Ordenamento do Território (GOT), no 18 (Dezembro). Centro de Estudos de Geografia e Ordenamento do Território, p. 153-178, dx.doi.org/10.17127/got/2019.18.007

\section{RESUMO}

Entre as décadas de 1990 e 2000, período da financeirização da economia no Brasil, as políticas públicas habitacionais brasileiras tiveram seus efeitos evidenciados em focos de irregularidade, periféricos à malha urbana, carentes de redes de infraestrutura básica, como na sede do município de Cascavel, Paraná, Brasil, que fez parte da região de fronteira de expansão de capital do sul do país a partir da década de 1930. Utiliza-se uma abordagem metodológica em dimensão multiescalar sobre as fontes documentais para evidenciar o panorama de atuação da Companhia Municipal de Habitação de Cascavel - COHAVEL, empresa pública, com fins econômicos, responsável pela promoção de loteamentos irregulares, direcionados para a população de baixa renda, desde a sua criação até o seu desmanche em 2010.

Palavras-chave: Produção da Irregularidade; Assentamentos Irregulares; Financeirização; Território; Cascavel/PR.

\section{ABSTRACT}

Between the 1990s and 2000s, the period of the financialization of the economy in Brazil, Brazilian public housing policies had their effects evidenced in outbreaks of irregularity, peripheral to the urban network, lacking basic infrastructure networks, such as in the municipality's headquarters of Cascavel, Paraná, Brazil, which was part of the frontier region of capital expansion in the south of the country from the 1930s. A methodological approach is used in a multiscale dimension on documentary sources to highlight the Company's performance landscape Municipal Housing Corporation of Cascavel - COHAVEL, a public 
company with economic purposes, responsible for the promotion of irregular subdivisions, directed to the low income population, from its creation, until it's dismantling in 2010.

Palavras-chave: Irregularity Production; Irregular Settlements; Financialization; Territory; Cascavel/PR.

\section{A produção da irregularidade urbana}

A "produção do espaço urbano" é um termo usado geralmente por geógrafos e cientistas sociais, com base nas teorias de Marx (2013), reorientadas por Lefebvre $(2011)^{40}$, para entender as contradições presentes na cidade. "A produção do espaço se insere na lógica da produção capitalista que transforma toda a produção em mercadoria" (Carlos, 2014: 60). Nesse sentido, é possível apreender o momento da história em que o espaço passa a ser fundamental (condição, meio e produto) para a reprodução de determinado modo de produção, sob o comando do capital, definindo práticas socio espaciais e suas normas, como maneira de legitimar acessos e apropriações diferenciadas (Carlos, 2014). A partir da materialidade incontestável do espaço, verifica-se que essa produção se dá igualmente nos espaços urbanos informais e excludentes, mesmo que com menor fluidez de capital, havendo então o pressuposto da "produção da irregularidade urbana". A irregularidade urbana pode ser definida, segundo Clichevsky (2009), como sinônimo de ilegalidade e de informalidade, e se relaciona às transgressões de agentes sobre o domínio da propriedade (como a falta de titulação ou contrato de aluguel) e ao processo de urbanização (descumprimento das normas edilícias, de uso e ocupação do solo e ambientais).

Diante da multiplicidade e da complexidade dos processos espaciais e da articulação dos diferentes agentes na transformação dos territórios urbanos, em países inseridos em contextos distintos, estudos vêm mapeando as realidades da produção da cidade capitalista e o seu caráter econômico, com destaque para o preço da terra e para a expansão do capitalismo, enfatizando as desigualdades urbanas nas quais uma das formas é a irregularidade urbana. Nas cidades latinoamericanas, de acordo com Clichevsky (2009), os agentes públicos e privados alteram-se na promoção da irregularidade urbana, devido às

\footnotetext{
${ }^{40} \mathrm{Na}$ concepção marxista, o capitalismo, antes de tudo, é um “modo de produção" econômico que gera a ordem jurídico-política na lógica do capital, independente do direito (Dardot e Laval, 2018). Alguns autores refletem sobre a articulação das reivindicações da sociedade e o espaço construído a partir do desenvolvimento dos conceitos de Marx e de outros autores marxistas, como Lefebvre (2011), Gottdiener (2010), Castells (2009), Carlos (2014), entre outros. Sob esta construção conceitual complexa analisa-se os espaços urbanos informais e excludentes como parte de um processo de produção da cidade.
} 
transformações nos planos econômicos, social e político, e articulam-se de forma muito complexa e de maneiras distintas. A desigualdade urbana aumenta, também, segundo Gonzáles-Pérez (2018), em países com altos níveis de desenvolvimento econômico, que possuem uma rede de segurança social e estado de bem-estar altamente desenvolvidos, bem como nos países que se comprometem com serviços privatizados e com a economia de mercado. Convém, portanto, incluir na análise o fenômeno em centros urbanos de menor porte e de formações recentes, onde se observam processos que se assemelham aos que vêm ocorrendo em diferentes contextos mundiais, mas com características muito distintas, como a passagem, em menos de um século, de território de expansão da fronteira agrícola para o de expansão de fronteira urbana, como é o caso do município de Cascavel, localizado no Oeste do estado do Paraná, Brasil, atualmente com 324.476 habitantes (IBGE, 2018).

A procura pela informalidade como opção no acesso ao solo urbano é resultante da inacessibilidade aos preços do mercado formal sobre o solo urbanizado para a população de baixa renda. Essa forma de ocupação do solo representa para seus usuários, mesmo que em situações precárias, a opção de preço mais acessível em relação a outra superior em recursos de infraestrutura, na sequência crescente de preços entre: terra nua, informal e urbanizada regular (Smolka, 2003). As discussões sobre autoconstrução e a informalidade nas cidades mostram que a opção informal ocasiona somente uma aparente baixa nos custos de vida, e só vem a aumentar a taxa de exploração da força de trabalho, com a diminuição dos salários reais (Oliveira, 2013). Os salários são determinados pelo custo mínimo necessário para a reprodução da força de trabalho (custos com alimentação, habitação, bens e serviços urbanos). Nesta lógica, com o barateamento da habitação, há uma diminuição reflexa dos salários (Oliveira, 2013). Estas sujeições forçam as taxas de adensamento intradomiciliar e coabitação, as soluções de autoconstrução e, consequentemente, forma um mercado de áreas irregularmente parceladas, com carência em infraestrutura para a baixa renda, na periferia das cidades (Smolka, 2003).

Para o estabelecimento de áreas irregulares na malha urbana, de acordo com o marco jurídico da Lei Federal brasileira $n^{0} 6.766 / 1979$, são necessárias desconformidades com a regulamentação urbanística, seja no âmbito municipal, estadual ou federal, o que acarreta a irregularidade cadastral do loteamento ou assentamento. Em consequência prática, há uma negligência intencional ao fornecimento de serviços e infraestrutura básica (vias de 
circulação, escoamento de águas pluviais, rede para abastecimento de água potável, soluções para esgotamento sanitário e energia elétrica domiciliar), devido à sua inexistência formalizada (Saule Jr, 2004). Nega-se aos moradores destas áreas, o direito de usufruir de todas as vantagens do suporte físico e de serviços do sistema urbano, essenciais para a reprodução da força do trabalho, aumentando o custo de vida (Gottdiener, 2010).

A promoção da irregularidade urbana com a conivência da municipalidade é um dado contraditório e intrigante. Nos vários perfis de atuação do poder público municipal sobre a cidade, quando se lista, junto ao seu caráter fiscalizador e regulador do uso do solo, também o de produtor imobiliário do espaço urbano, as bases de afirmação somente sob o marco jurídico apresentam-se insuficientes para uma análise das diferentes respostas na infraestrutura da rede técnica urbana de promoção pública (Corrêa, 2005).

Telles (2010) explica que, a partir da financeirização da economia ${ }^{41}$ no Brasil, os processos de urbanização foram desestabilizados para se relacionar aos problemas de gestão urbana das urgências firmada pela racionalidade do mercado. Na gestão (regulação/administração) de urgências do sistema urbano, o Estado, em suas instâncias governamentais, pode dirigir, ou não, o investimento em infraestrutura para determinados lugares na cidade, sob o pretexto da necessidade coletiva (Carlos, 2007). Pode-se afirmar que a intervenção do governo sobre o espaço urbanizado torna sempre o valor de troca mais fluído. Isso proporciona o uso destas relações de fluidez de valor de troca na gestão do sistema urbano, observável nas diferentes respostas de implantação das redes técnicas de infraestrutura e não sobre a necessidade de seus usuários (Gottdiener, 2010).

Para o esclarecimento destas questões, parte-se de um enfoque sobre a mercantilização da terra urbana, quando algumas cidades na região de fronteira de expansão do capital ${ }^{42}$ sofrem com processos de adensamento e industrialização. As variáveis atingem a região Oeste do estado do Paraná, localizada ao sul do Brasil, e incitam o fenômeno da

\footnotetext{
${ }^{41}$ Financeirização mundializada do capital é o termo utilizado quando há abertura para o financiamento externo da acumulação de capital. Isto gera vários fenômenos como a sobredeterminação do capital financeiro sobre o produtivo e o deslocamento do capital para periferias remotas, fronteiras que nada contavam para a acumulação mundial (Oliveira e Rizek, 2007).

${ }^{42}$ A fronteira são limites de exceção, em momentos de contradição e conflitos, onde se encontra a população fora da fronteira econômica, e por algumas características, ainda são locais profícuos de investimentos, novas áreas para o estabelecimento do capital ou seja, mesmo que à margem da legalidade, um espaço pronto para ser incorporado ao restante da cidade e suas regras (Martins, 1996; Mautner, 2010).
} 
irregularidade, identificadas nas deficiências em infraestrutura e na ausência de titulação na área urbana.

Como exemplo desse fenômeno, aborda-se a produção da irregularidade urbana da Companhia Municipal de Habitação - $\mathrm{COHAVEL}^{43}$, do município de Cascavel, em duas práticas espaciais: os assentamentos irregulares, formados pelo reparcelamento ou ocupação de áreas em loteamentos aprovados, e os loteamentos irregulares, em glebas não parceladas anteriormente. O período analisado abrange os anos de 1990 a 2000, período de maior atuação da COHAVEL, embora se amplie o marco temporal, contemplando a formação do território, na década de 1960, até o anúncio do desmanche do órgão municipal no ano de 2012.

A base documental dos processos com solicitações, principalmente, para ligação de água à Prefeitura Municipal de Cascavel, deram origem a protocolos no setor de Regularização Fundiária. Os dados quantitativos resultantes demonstram que, desde a década de 1970 a cidade de Cascavel indica em sua malha urbana o surgimento de áreas irregulares/clandestinas por meio da promoção de agentes privados, no total de três casos até a década de 1980. Após este período, conforme levantamentos do Plano Municipal de Habitação - PMH do município de Cascavel, principal corpus documental desta pequisa, formulado pela secretaria de planejamento municipal, houve o estabelecimento de 25 áreas entre assentamentos e loteamentos irregulares na sede urbana, ao se considerar somente as áreas de promoção pública (Cascavel, 2012). Ainda que, 16 destas áreas (64\%) foram de promoção da empresa pública municipal: a Companhia Municipal de Habitação de Cascavel - COHAVEL. Portanto, entre as décadas de 1990 e 2000, a COHAVEL foi o grande agente promotor da irregularidade presente na cidade. Constata-se que a companhia desempenhou um papel local mediador no mercado imobiliário, da frente de expansão capitalista $^{44}$, quando da produção de parcelamentos irregulares para habitações periféricas, neste momento específico de flexibilização do capital (Soares, 2016).

\footnotetext{
${ }^{43}$ Fundada em 1992, a COHAVEL é uma empresa pública municipal, com fins econômicos e patrimônio próprio, subordinada diretamente ao prefeito municipal, encarregada de desenvolver políticas e projetos de habitação popular, também o planejamento urbano, podendo celebrar convênios com outros órgãos públicos ou iniciativa privada para a construção de habitações (Cascavel, 2012).

${ }^{44}$ A frente de expansão capitalista expressa a concepção de ocupação do espaço tendo como referência a população excluída na fronteira econômica, ainda em relações simples de mercantilização, sem a propriedade formal, mas com possibilidade de posse da terra (Martins, 1996).
} 
Como método de investigação desta pesquisa, adotou-se a abordagem em níveis multiescalar focado nas problemáticas das políticas econômicas desenvolvidas nas décadas de 1930-60-90, que incorreram para a migração, adensamento das cidades brasileiras e estabeleceram a financeirização da economia (Oliveira, 2013). Conforme Barbieri (2007), um marco conceitural multiescalar reconhece que as variáveis explanatórias da relação (mercantilização, adensamento e industrialização na fronteira de expansão do capital), afetando a urbanização e a irregularidade urbana, mudam quantitativa e qualitativamente à medida que a escala de análise se altera, tanto no espaço quanto no tempo. Por isso, os fatores causais na relação entre mobilidade populacional, meio ambiente produzido e uso da terra devem ser entendidos como dependentes entre as escalas e níveis, mesmo que resultantes da operação de fatores diferentes (Barbieri, 2007).

A seguir, aborda-se o panorama no Paraná a partir da década de 1930 e os reflexos da passagem econômica de base agrário-exportadora para a urbano-industrial no Brasil e na região de Cascavel/PR, que são estruturantes para o entendimento do adensamento das cidades brasileiras e da formação da irregularidade urbana local. Na sequência discorre-se sobre o papel da COHAVEL como promotora da irregularidade urbana, com seu início na década de 1990. Por fim, discute-se o desmanche desta companhia na década de 2000, a partir do estabelecimento da concepção de financeirização na periferia da cidade, decorrente das mudanças de paradigmas da habitação de interesse social.

\section{A região de fronteira de expansão do capital e a inserção de}

\section{Cascavel}

O território de Cascavel constituído no processo de ocupação da região Oeste é produto das relações de trabalho e das relações de produção que atingiram o estado do Paraná e está diretamente relacionado ao seu desenvolvimento econômico proveniente da "integração simbiótica" entre urbano e rural (Oliveira, 2013).

Nos limites deste texto, não é possível aprofundar as etapas fundamentais da gênese do território de Cascavel e da sua importância como fronteira de expansão do capital. Todavia, destacam-se algumas características de sua formação como polo regional, localizado em confluencia viária de escoamento de matérias-primas, e de sua incorporação à gestão da 
fronteira capitalista, com a intervenção política a partir de meados da década de 1930 . A crescente importância dos caminhos à Foz do Iguaçu e sua ligação fronteiriça com o Paraguai e Argentina foram determinantes para o desenvolvimento do núcleo urbano de Cascavel (Reolon, 2007) (ver figura 01), além de outros motivos de integração nacional na “Marcha para o Oeste" ${ }^{45}$, de 1943, como os fluxos migratórios resultantes da divulgação de venda de lotes de colonização privada na região e o incentivo a correntes colonizadoras de promoção federal (Mariano, 2012).

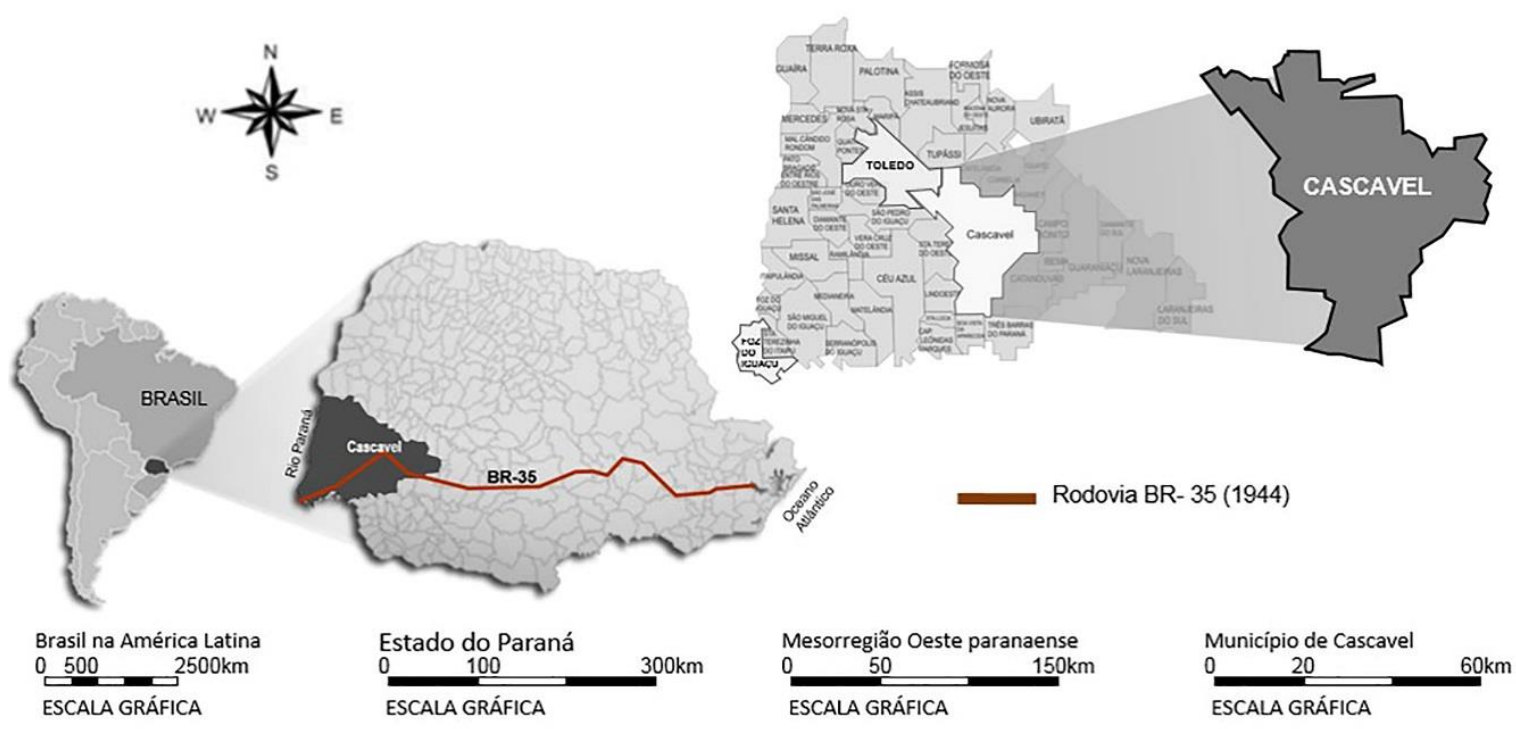

Fig. 1 - Localização do Município na mesorregião Oeste do Paraná, com rodovia BR-35, 1990 Fonte: Soares et al. (2018: 2)

Aliadas às políticas nacionais de transportes, como apoio ao escoamento e à extração madeireira, duas importantes rodovias protagonizaram a relevância da logística na circulação de matérias-primas para gênese e desenvolvimento do município, na esteira do processo de expansão. A BR-35, de 1944, e a BR-277, de 1958, cumpriram funções de ligação do interior ao litoral (via Porto de Paranaguá), aos portos do rio Paraná e a Foz do Iguaçu. Ambas cruzavam o território do município que tem a sua prosperidade relacionada à sua localização junto às rodovias (Mariano, 2012). Também, à flexibilização mercantil que, entre as décadas de 1930 e 1950, uniu os interesses do setor primário (agrícola) e do setor

\footnotetext{
${ }^{45}$ A "Marcha para o Oeste" foi um programa federal (1937-1945) com projetos de incentivo à ocupação dos vazios demográficos do interior brasileiro e das fronteiras nacionais, com o objetivo de diminuir as diferenças regionais devido aos séculos de ocupação litorânea e para uma integração nacional. As colônias agrícolas teriam um papel fundamental, juntamente com a política de transportes. No Paraná, esta região abrangia basicamente o município de Foz do Iguaçu (Soares, 2016; Mariano, 2012).
} 
terciário (comercial) (Oliveira, 2013). Os interesses econômicos dos madeireiros e dos adquirentes dos lotes convergem para o estímulo do comércio da madeira, ou seja, a extração da madeira, que é a matéria-prima para beneficiamento nas serrarias, promovia a terra limpa para o cultivo diversificado. Portanto, formaram um "elo vital" entre os setores, conciliando os ganhos dos dois setores (Piaia, 2013) e, nas décadas seguintes, com o dinamismo da economia regional, forneceram subsídios à industrialização e valorização do capital das demandas nacionais.

Com a diversificação do trabalho e a introdução do trabalho assalariado, após os anos 1930, houve a dissolução das necessidades iniciais da frente de expansão que estruturaram o traçado inicial do núcleo urbano e a ação do Governo do Estado foi determinante para esta modificação, com a doação e implantação de uma nova área para a expansão da cidade, no Patrimônio Novo, e a readequação dos lotes urbanos já existentes, do Patrimônio Velho, em 1959 (ver figura 02). Convém esclarecer que, denomina-se de Patrimônio Velho a área total de 500 ha delimitada por lotes foreiros desde 1936. Em seguida, em 1954, o Governo do Estado do Paraná realiza a doação de aproximadamente 400 ha da área chamada de Patrimônio Novo, implantada contígua ao Patrimônio Velho.

Com o Patrimônio Novo, promove-se o crescimento horizontal, atuando na venda dos lotes e na reconfiguração da morfologia da planta existente por meio de lei municipal, em 1957, o que, todavia, não evitou conflitos de propriedade e titulação. Na produção do espaço há a subordinação do solo urbano antes obtido por aforamento ${ }^{46}$, ao valor de troca, submetendo o uso às necessidades do mercado imobiliário, com redefinições precisas entre terrenos e vias (Carlos, 2007). A readequação da malha existente foi o primeiro marco visando a titularidade de terras e das intenções da frente pioneira na mercantilização destas (ver figura 02) (Soares, 2016; Martins, 1996).

Com o estabelecimento das condições urbanísticas para a entrada e reprodução do capital imobiliário, mesmo que dificultada pelas situações de violência e coação na disputa pela terra, tem-se um panorama do processo histórico de formação do território de Cascavel até a década de 1960. A partir deste marco, observa-se uma sucessão da expansão urbana e

\footnotetext{
${ }^{46}$ No documento de aforamento, só se concede privilégios e deveres sobre uma propriedade, para exploração ou usufruto do ocupante, dada pelo proprietário. Este documento era um "direito alienável e transferível aos herdeiros e que conferia a alguém o pleno gozo do imóvel mediante a obrigação de não deteriorá-lo e de pagar um foro anual em dinheiro ou espécie" (Myskiw, 2002: 171).
} 
populacional na sede do Município (Piaia, 2013). Na política de implantação de infraestrutura, permanece o interesse imobiliário e não a resolução dos problemas de consumo coletivo das massas.
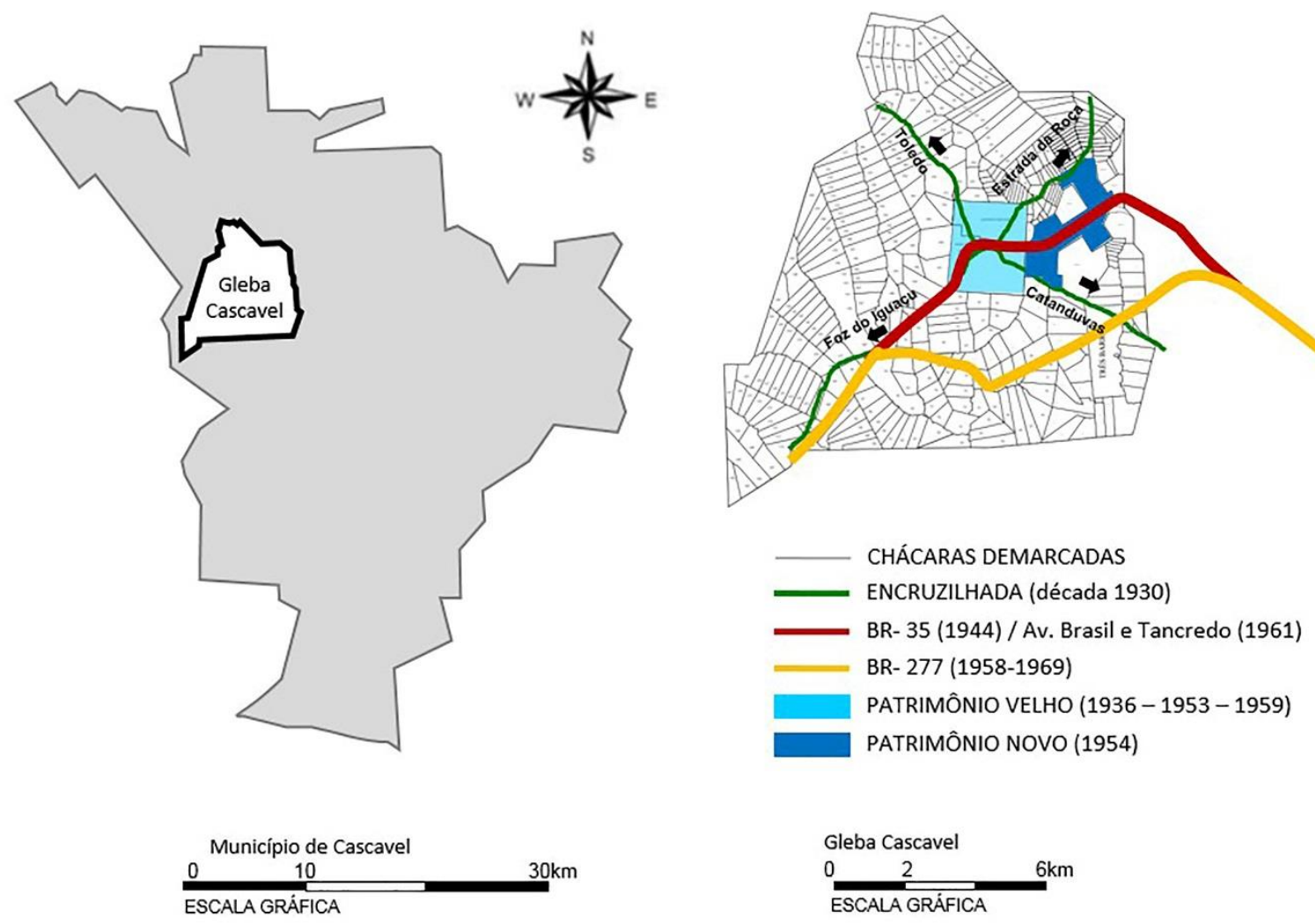

Fig. 2 - Município, Gleba Cascavel, Encruzilhada, Patrimônio Velho e Patrimônios Fonte: Soares (2016)

\section{A urbano-industrialização no Paraná e a atratividade de}

\section{Cascavel entre 1960 a 1980}

O panorama político-econômico que se estabeleceu a partir da década de 1960, que forma as condições necessárias para a expansão do mercado interno brasileiro, orientando o processo de acumulação da empresa industrial, com baixos coeficientes de capitalização oportunizados na expansão da ocupação da terra, tem suas condições institucionais formadas a partir do Estado Novo (1937-1945), a mesma ideologia posteriormente empregada no "Plano de Metas" (1956-1960) do governo Federal (Oliveira, 2013). A concepção desenvolvimentista baseada na teoria keynesiana se explica na noção, de apelo 
nacionalista, de um Estado indutor do crescimento econômico, em um país subdesenvolvido. A autossuficiência econômica requeria a industrialização em substituição às importações, com isso, desenvolveu-se a indústria de base, a infraestrutura de estradas e hidrelétricas, mas também, em contraponto, penalizou-se a inclinação agrário-exportadora do expoente café (Oliveira, 2013). Como resultado, há a passagem econômica da base agrário-exportadora do país para a urbano-industrial em 1960.

A ditadura militar (1964-1985) não significou a mudança de modelo (Oliveira e Rizek, 2007), e a mesma ideologia foi adotada nas medidas de racionalização do plano de governo paranaense em ações estruturantes. Como resultado, no decorrer da década de 1960, houve a expansão da malha rodoviária do Estado, garantindo que o escoamento das safras se desse pelo Porto de Paranaguá, e nas décadas seguintes, outras rodovias interligaram-no em outras direções. Para Cascavel, além da importância já ressaltada da BR-277, a abertura das rodovias BR-467 (Cascavel-Toledo) e BR-369 (Cascavel-Maringá), próximas também a seu núcleo urbano, na década de 1990, integraram-na à rede nacional de cidades.

Nos anos do "Milagre Brasileiro" (1967-1973), há conjuntura para o expressivo crescimento industrial no Paraná, principalmente, em dois setores privilegiados em financiamentos: a indústria pesada e a agroindústria. A última por suas vantagens na concorrência com outros estados na produção de soja, madeira e carne (Oliveira, 2002). O grão de soja, juntamente com seus derivados de farelo e o óleo, foi o produto principal de exportação paranaense. Beneficiando-se da massa falida da atividade principal, a exportação da carne e derivados representaram uma atividade secundária em ampla expansão (Belusso, 2014). Há o esgotamento da exploração da madeira por serrarias, e a implantação da cultura da soja em latifúndios de monocultura compelem para o êxodo rural do pequeno agricultor paranaense (Oliveira, 2002; Sperança, 2007).

A proposta política do Estado, nas décadas de 1970-1980, focou no crescimento populacional das cidades existentes e foi percebida na redução de criação de novos núcleos urbanos (Oliveira, 2002). Há uma ação intencional para o desenvolvimento de cidades consideradas de porte médio para que cumprissem o papel de "diques" para conter os fluxos migratórios em direção às metrópoles do Sudeste do país (Andrade e Serra, 2001; Reolon, 2007). Outra orientação para a aplicação de concessões de crédito indicavam que o tamanho urbano e a localização espacial não afetavam substancialmente a produtividade 
industrial, oportunizando o deslocamento dos parques industriais, sem a perda sensível de eficiência ou ritmo econômico (Andrade e Serra, 2001). A designação primeira de financiamento voltada à concentração industrial na região de Curitiba, até a metade da década de 1970, sofre mudanças radicais em nova reconcentração espacial para as duplas de cidades: Curitiba-Ponta-Grossa; Londrina-Maringá e Cascavel-Toledo (Reolon, 2007).

Para ilustrar as decorrências das políticas de financiamento em infraestrutura e deslocamento do parque industrial, os estudos de Tschá et al (2014) e Reolon (2007) demonstraram a diferença do grau de urbanização dos municípios mais representativos da região Oeste do Paraná, evidenciado na relação entre população rural e urbana, a partir da década de 1960 até a de 2000 (ver figura 3).
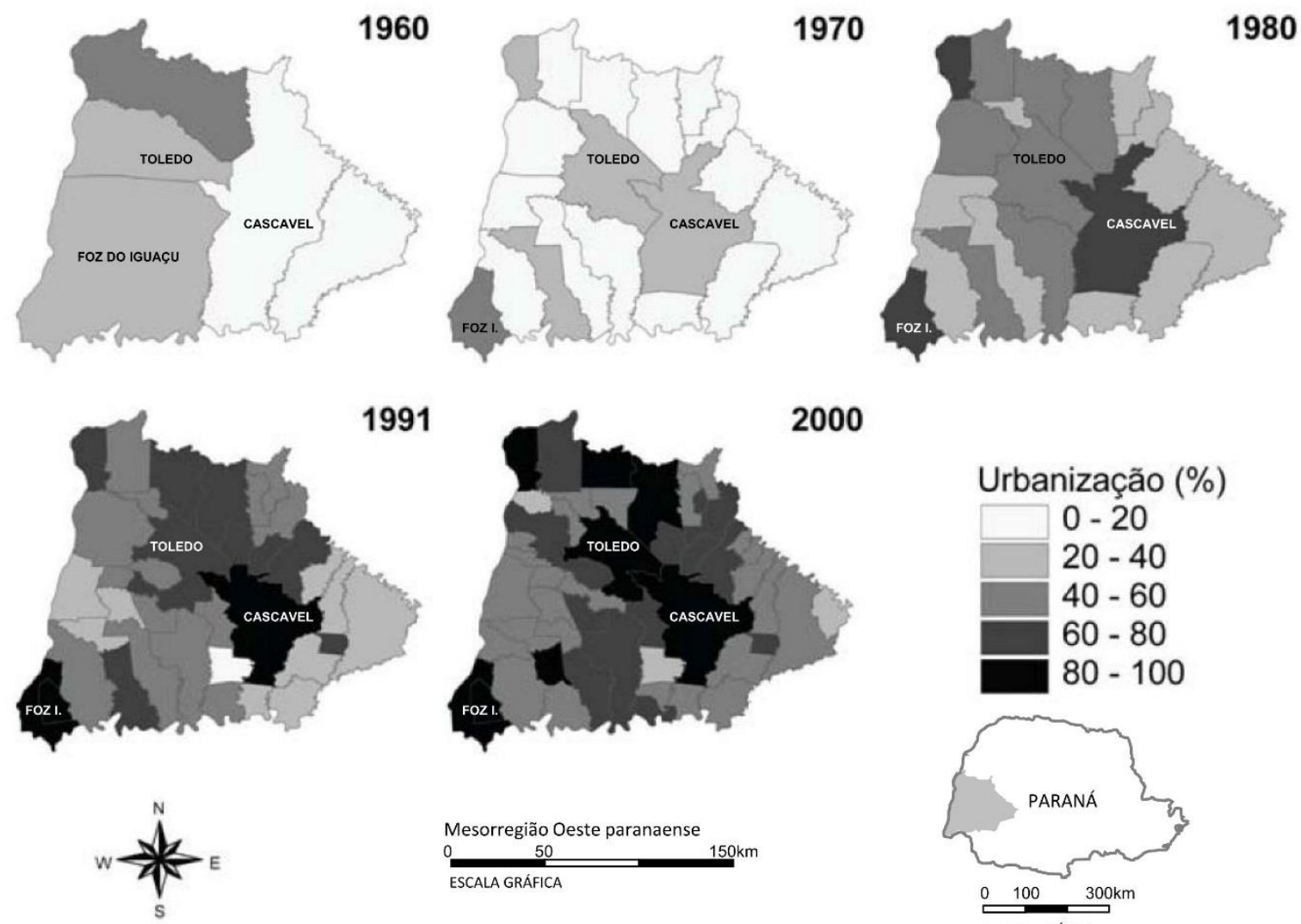

1991
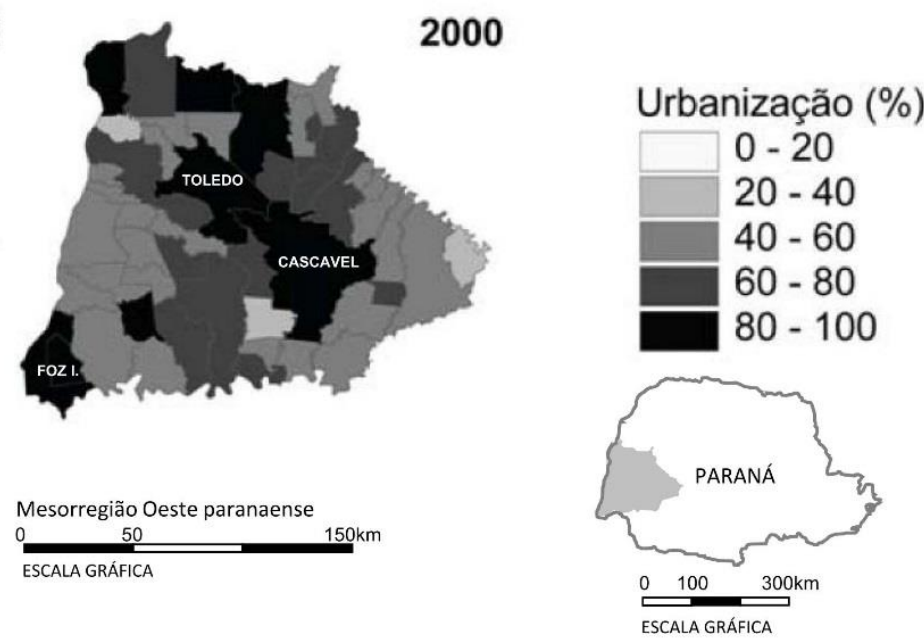

Fig. 3 - Urbanização dos Municípios da Mesorregião Oeste paranaense Fonte: Reolon (2007: 101)

Observa-se na figura 3, com gradações de cinza, na comparação entre as cidades de Foz do Iguaçu (67,23\%) e Cascavel (41,26\%), que, na década de 1970, o primeiro município apresenta uma população urbana superior do que Cascavel, ainda predominantemente 
rural. A razão se altera na década seguinte, com a inversão do processo migratório, o percentual da população urbana de Foz do Iguaçu $(74,96 \%)$ é menor do que a do seu antigo distrito, Cascavel (83,29\%). Nas décadas de 1990 e 2000, com a economia estabilizada no país, os municípios de Cascavel, Foz do Iguaçu e Toledo mantiveram um alto percentual de urbanização, acima de 90\%, mesmo com a diminuição no incremento de variação populacional, indicando mudanças em suas funcionalidades (ver figura 3) (Andrade e Serra, 2001).

No Oeste do Paraná, uma das justificativas do aumento populacional nos municípios que conseguiram fortalecer a transição entre o urbano-rural para o urbano-industrial está na atração de contingente de trabalhadores para a construção da usina hidrelétrica Binacional de Itaipu, entre as décadas de 1970 e 1980, a partir da indenização compulsória das desapropriações de áreas nas proximidades do rio Paraná (Tschá et al., 2014).

Os motivos para a rápida acomodoação do município de Cascavel nesta política são justificadas, principalmente, sobre suas condições climáticas e geofísicas para a mecanização na exploração da monocultura da soja, produto que apresentou alguma vitalidade devido à política cambial favorável da década de 1980 (Tschá et al., 2014; Belusso, 2014; Sperança, 2007). Nesse processo, o pequeno produtor conseguiu acesso à modernização dos minifúndios quando ligado ao setor privado das cooperativas agroindustriais, que se tornaram economicamente viáveis com a diversificação de culturas, a partir da década de 1970, incorporando-se ao mercado também para a comercialização de produtos de consumo humano como lacticínios (Belusso, 2014; Sperança, 2007).

Novamente a localização da cidade de Cascavel, coincidente com o polígono rodoviário do Anel de Integração Estadual implantado nos anos de 1990, firmaram-na como uma ponte de produção e distribuição de bens e serviços de consumo, tanto como grande fornecedor auxiliar à construção da usina hidrelétrica Binacional de Itaipu, quanto para os municípios de seu entorno, ou no acesso aos bens produzidos extrapolando à região (Reolon, 2007).

Oliveira (2013) explica que o processo de crescimento das cidades não pode ser entendido sem a noção de que as bases técnicas, com as exigências de qualidade, quantidade e padronização das indústrias, pouco absorvem o fluxo de mão-de-obra. A formação de núcleos industriais dinamizam outros setores industriais como no fornecimento de matéria- 
prima e fluxo de produção (armazenamento, processamento e distribuição), e tem, nas cidades, importantes bases de interligação das operações comerciais e de serviços. O estudo de Tschá et al (2014) apresentam a transformação produtiva da mesorregião oeste do Paraná e, como parte da análise, uma tabela com a distribuição do emprego formal que pode ilustrar esta questão.

Tabela 1 - Emprego formal em setores de atividades com mais de 4 mil postos de trabalho em Cascavel, Toledo e Foz do Iguaçu, 1990-2001

\begin{tabular}{|l|l|r|r|r|}
\hline Setores de actividades & \multirow{2}{*}{ Ano } & \multicolumn{3}{|c|}{ Município } \\
\cline { 3 - 5 } & & Cascavel & Toledo & Foz do Iguaçu \\
\hline \multirow{3}{*}{ Indústria de } & 1990 & 2555 & 4792 & 398 \\
\cline { 2 - 5 } & 1995 & 5110 & 5017 & 676 \\
\cline { 2 - 5 } & 2001 & 5422 & 7011 & 635 \\
\hline \multirow{4}{*}{ Agricultura } & 1990 & 1012 & 145 & 73 \\
\cline { 2 - 5 } & 1995 & 1912 & 941 & 183 \\
\hline \multirow{4}{*}{ Comércio } & 2001 & 2285 & 832 & 199 \\
\hline \multirow{4}{*}{ Serviços } & 1990 & 8589 & 2289 & 7129 \\
\cline { 2 - 5 } & 1995 & 9798 & 2875 & 8283 \\
\hline \multirow{3}{*}{ Construção Civil } & 2001 & 13165 & 3753 & 10575 \\
\hline & 1990 & 11838 & 5589 & 14087 \\
\cline { 2 - 5 } & 1995 & 14642 & 4403 & 17141 \\
\cline { 2 - 5 } & 2001 & 20278 & 7160 & 19043 \\
\hline & 1990 & 2293 & 314 & 4051 \\
\cline { 2 - 5 } & 1995 & 2963 & 327 & 1709 \\
\cline { 2 - 5 } & 2001 & 2491 & 613 & 2227 \\
\hline
\end{tabular}

Fonte: Tschá et al. (2014: 14)

Na tabela 1 observa-se que entre os anos de 1990 a 2001, em Cascavel houve um aumento nos postos de trabalho da indústria, pouco menor que Toledo, mas também um vertiginoso aumento nos postos de comércio e serviços, ultrapassando os de Foz do Iguaçu. Os dados sobre a agricultura se mantém superiores aos dois outros municípios de análise.

O tamanho do terciário formado, do ponto de vista de sua participação no emprego formal total, está ligado à acumulação urbano-industrial e são pontos ressaltados para a grande atratividade da região quando se considera a demanda por força de trabalho (Tschá et al., 2014). A análise só confirmou que, em Cascavel, a relação do aumento populacional com as atividades do setor terciário está intimamente relacionada com o setor primário, na subserviência às cooperativas de minifúndios, fundada nos baixíssimos custos da força de trabalho, dando subsídio capital para a formação e expansão da agro-indústria (Oliveira, 
2013). Esses baixos custos forçam também o aumento do setor informal da economia urbana, pela mão-de-obra desqualificada que migra às cidades, ocupando de forma precária loteamentos irregulares, cujo resultado aparente é o caos da cidade (Oliveira, 2013).

\section{Financeirização e promoção da irregularidade urbana: o papel da COHAVEL}

Na década de 1980, o "tripé desenvolvimentista" (empresas estatais/empresas privadas nacionais/empresas multinacionais), formado na ditadura militar, incorre para uma crise da dívida externa, restringindo financiamentos (Oliveira e Rizek, 2007). Além disso, marca um período de recessão econômica e de migração intensa no país.

Dentro do panorama de descapitalização do pequeno produtor à enorme massa de capital financeiro em circulação nas periferias de acumulação, principalmente com planos de infraestrutura para cidades de médio porte, a construção da hidrelétrica binacional de Itaipu entre outras obras de infraestrutura de ligação à rede nacional de cidades de promoção de nível Federal, localmente o incentivo à construção civil a partir de obras públicas foi o caminho adotado pelas gestões municipais em Cascavel para a geração de empregos a partir de meados da década de 1980 (Sperança, 2007). Há o incentivo municipal em atendimento ao consumo coletivo em áreas já consolidadas, com a construção de equipamentos públicos de saúde, saneamento básico, terminais de transbordo no transporte coletivo, construção de salões comunitários e parques ecológicos de lazer espalhados pela malha urbana (Sperança, 2007). Na produção de parcelamentos de novas áreas urbanas, segundo a Secretaria de Planejamento (Cascavel, 2014), na malha urbana de Cascavel, no período de 1986 a 1988, 33,00\% são conjuntos habitacionais com parceria do governo municipal com a companhia habitacional do Governo do Estado, ou com cooperativa de iniciativa privada (Sperança, 2007).

Na resultante destas ações, a tabela 1 mostra os números do emprego formal da construção civil no município de Cascavel, mantendo uma média alta e relativamente estável para a região entre os anos de 1990 e 2001, e sendo, inclusive, maior que a de Foz do Iguaçu e Toledo no ano de 1995. 
Com o desponte da cidade como polo regional de serviços devido à redistribuição dos polos industriais e financeirização, incentivados pelo Governo Federal e Estadual, o intuito de manter a produção habitacional local em apoio à construção civil foi evidenciada na Lei Municipal $n^{\circ}$ 2.345/1992, que criou a COHAVEL (Cascavel, 1992). A instituição pública foi aperfeiçoada e recriada em 1994, para atender a clientela provinda de áreas consideradas inapropriadas para a habitação (Sperança, 2007).

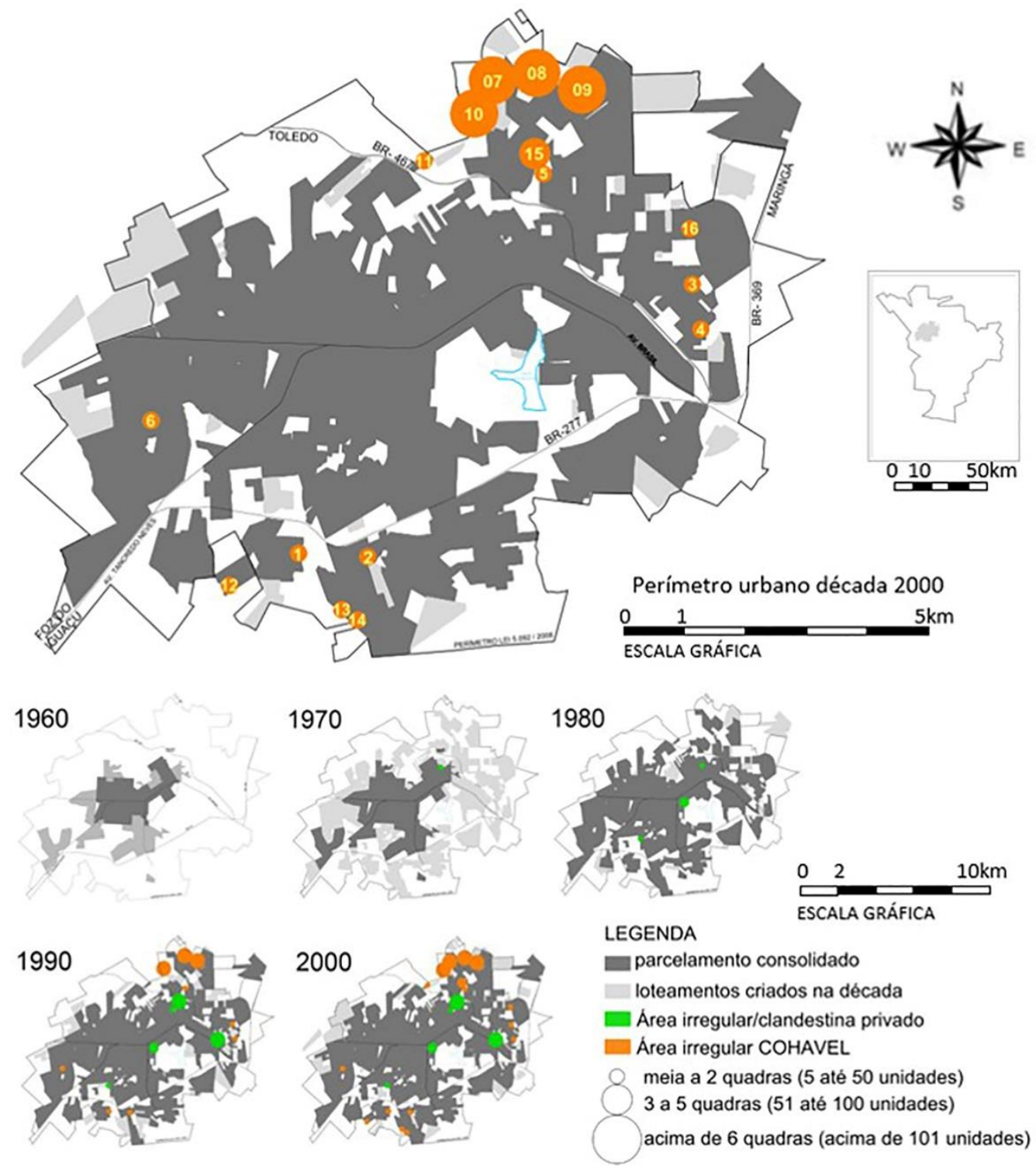

Fig. 4 - Mapa de evolução da ocupação do solo nas décadas de 1960-2000, destaque à promoção da COHAVEL na década de 2000

Fonte: (Soares, 2016)

A partir dos dados disponibilizados pela Prefeitura Municipal de Cascavel sobre os loteamentos regularmente aprovados (Cascavel, 2014), entre outras fontes, tem-se a 
evolução da ocupação do solo de forma regular e das áreas irregulares urbanas promovidas pela ação da COHAVEL e outros agentes particulares, demonstrado na figura 4.

Na figura 4, sob o contorno do perímetro urbano dado pela Lei Municipal $n^{0} 5.092 / 2008$, nota-se, em gradações de cinza, a abertura de novas áreas de loteamentos regulares, desde a região central com o primeiro núcleo urbano na década de 1960 e as expansões urbanas desconexas, deixando vazios urbanos nas décadas de 1970 e 1980. Como resultado da atuação municipal na gestão do solo urbano, nas décadas de 1990 e 2000, observa-se o preenchimento da malhas urbana regular e a permissão da intensificação da irregularidade urbana.

A irregularidade urbana já ocorria nas décadas de 1970 e 1980, pela promoção privada, implantadas em áreas próximas a malha urbana já consolidada, beneficiando-se da infraestrutura deste prosicionamento (ver figura 5). Diferentemente, a irregularidade promovida pela COHAVEL, se desenha na periferia da cidade, onde a malha urbana é descontínua e, em alguns casos, com infraestrutura inexistente. Os empreendimentos são implantados externos às barreiras ou limites das rodovias que cortam a cidade: BR-277 (sul); entre a Avenida Brasil e Avenida Trancredo Neves, saída para Foz do Iguaçu (oeste) e entre as BR-369 e BR- 467 (nordeste). Esta última região, foi a detentora da maior quantidade de assentamentos irregulares, bem como de todos os loteamentos também ilegais (ver figura 4).

A partir dos processos documentais de cada caso, levantou-se que as produções com parceria entre a Prefeitura Municipal e a COHAVEL partem de um projeto urbanístico que atende parcialmente a regularidade físico-territorial quanto à proposta de organização dos lotes e abertura de vias internas de circulação, ortogonais às existentes. Umas das variáveis da irregularidade apresentada é o tipo de manutenção do monopólio, com a efetiva doação ou não do imóvel para o patrimônio da COHAVEL, e a outra variável é a prática espacial destes lotes. Na organização destas variáveis foram identificados casos distintos, sendo os que, com particularidades de monopólio, atendem a prática espacial de reparcelamento em área já loteada e regular, e, os casos com a proposta de parcelamento de gleba em terra nua. Nos limites deste trabalho, identificam-se dois casos que exemplificam as duas variáveis. 
a) No primeiro caso, desenvolve-se o projeto urbanístico de reparcelamento em áreas destinadas à utilidade pública (de previsão de equipamentos de educação, saúde, lazer, etc.), em loteamentos já aprovados, com a edificação de casas executadas pela COHAVEL. A propriedade permanece do Município, mesmo com cobrança de prestações sendo feitas pela COHAVEL. Possuem estas condições algumas quadras em três loteamentos, que formam um total de 115 lotes, em 4,41 ha.

A exemplo, demonstra-se a implantação do Loteamento Quebec, aprovado no ano de 1997, no bairro XIV de Novembro, na região sul da cidade (ver figura 6). O projeto foi implantado no ano de 2001, na quadra 14, de utilidade pública, com zoneamento parcialmente sobre uma área de fundo de vale e preservação permanente (cor verde e vermelha na figura 5). Nesta situação, o parcelamento dos lotes deveria atender minimamente a dimensão de $600,00 \mathrm{~m}^{2}$. Contudo, a proposta resultou em 30 lotes com dimensões de $180,00 \mathrm{~m}^{2}$, com edificações em alvenaria de $38,40 \mathrm{~m}^{2}$.
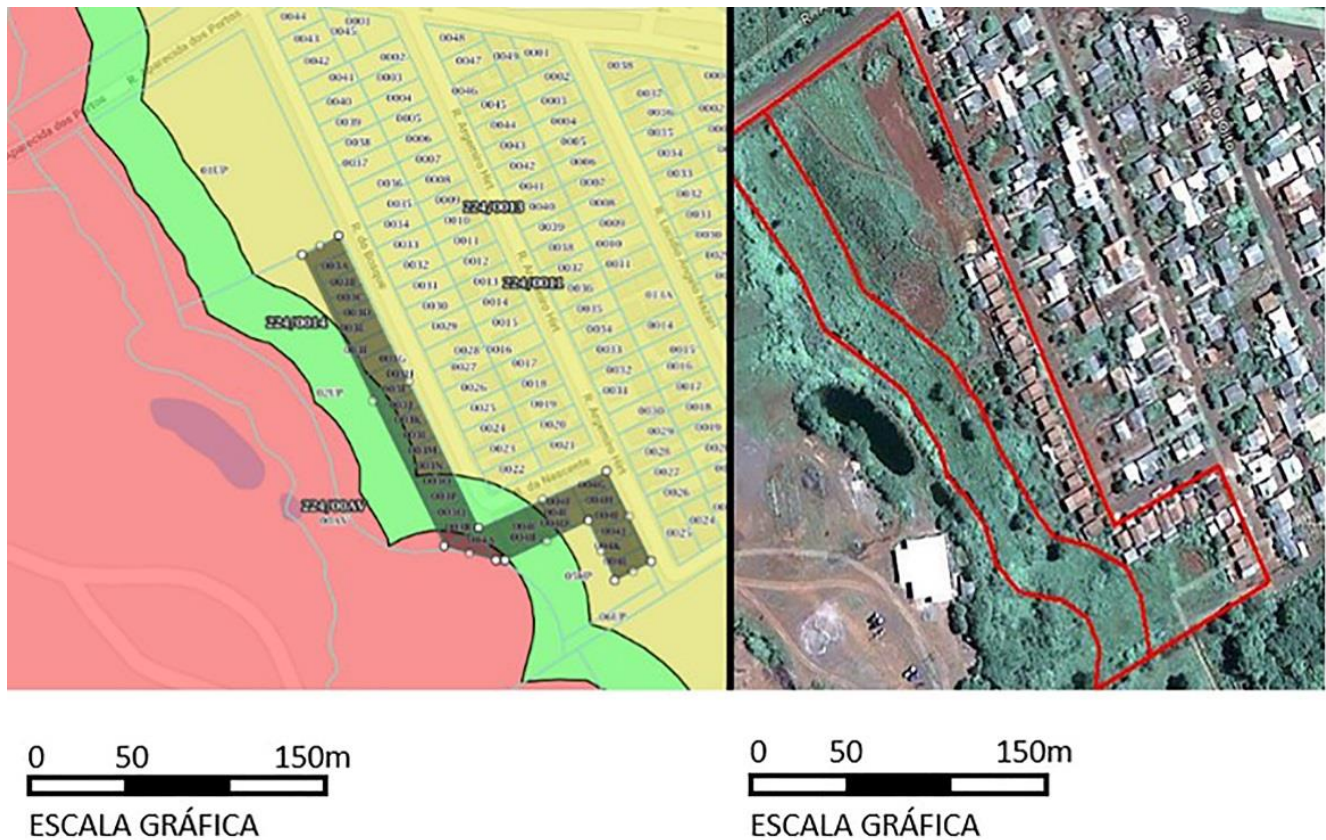

\section{LEGENDA}

Área preservação permanente (proibido edificações)

Área de Fundo de Vale (restritivo)

Área de lotes normais conforme zoneamento

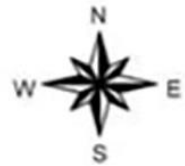

Fig. 5 - Detalhe Mapa Zoneamento e Implantação da Quadra 14, Lot. Quebec Fonte: Município de Cascavel 2014; Google Earth 2018 (modificado) 
b) No segundo caso, ocorre a doação de área para a COHAVEL, que desenvolveu o projeto urbanístico de um loteamento totalmente novo. Em alguns casos foram implantados conjuntos habitacionais. Devido ao não atendimento em metragens mínimas de lotes ou das quantidades de áreas destinadas a ruas ou à utilidade pública, o parcelamento não foi aprovado. Foram afetados pelo problema as glebas que configuram 4 loteamentos irregulares, que somam 1303 lotes, em 55,10 ha.

Para ilustrar, o exemplo do loteamento irregular Melissa, implantado no ano de 1994, na região norte da cidade, com um parcelamento de 380 lotes de aproximadamente $240,00 \mathrm{~m}^{2}$, dispostos em 25 quadras. Ocorreu somente a venda dos lotes, permitindo-se o sistema de autoconstrução pelos adquirentes (ver figura 6). Neste caso, o arruamento em larguras menores do que o exigível e falta de culde-sac ao final das ruas que atingiam o fundo de vale foram o impeditivo da sua aprovação.
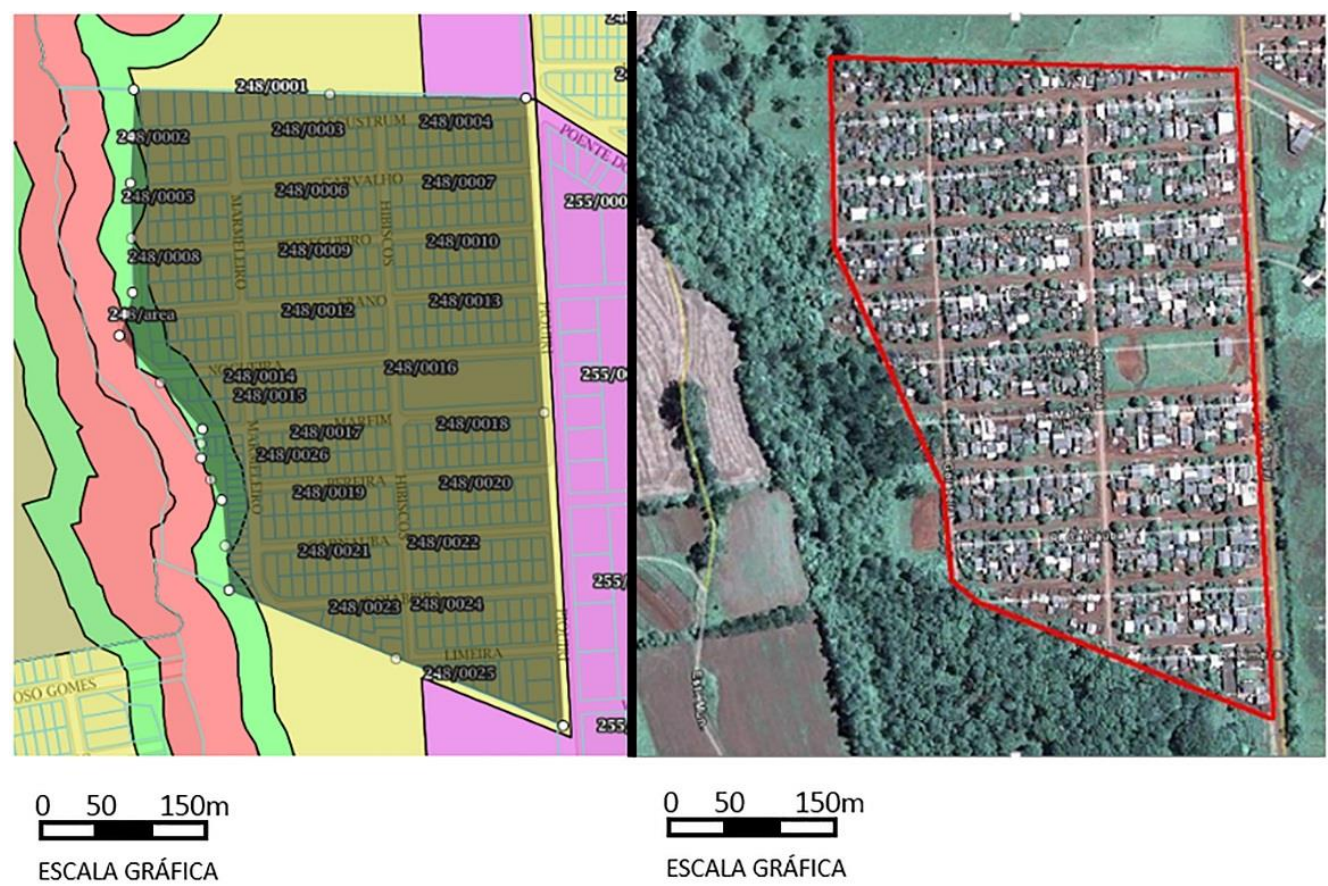

LEGENDA

$\square$ Área preservação permanente (proibido edificações)
$\square$ Área de Fundo de Vale (restritivo)
$\square$ Área de lotes normais conforme zoneamento

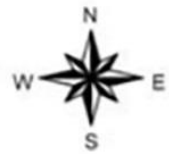

Fig. 6 - Detalhe Mapa Zoneamento e Implantação Lot. Melissa Fonte: Município de Cascavel 2014; Google Earth 2018 (modificado)

Sobre as características encontradas nestas áreas irregulares, podem ser consideradas em loteamentos à margem da legalidade, com a reprodução de um espaço pronto para ser 
incorporado ao restante da cidade, por seguir as formas tradicionais do traçado da cidade, fazendo o papel da frente de expansão capitalista (Martins, 1996). "Se seguissem estritamente os requisitos legais para serem vendidos, estariam certamente fora do alcance da população de baixa renda; porém, quanto mais próximos chegam dos padrões tradicionais, maiores são as chances de serem alcançados por serviços urbanos" (Mautner, 2010: 253).

A promoção da irregularidade urbana pela COHAVEL contabiliza 1.669 lotes, atendendo uma estimativa populacional de 7 mil pessoas, sobre uma área de 65,68 ha, que, somando-se ao total de áreas regulares de expansão urbana, representa 5,64\% do total parcelado nas décadas de 1990 e 2000. Destaca-se que dez destes locais são da década de 1990, que somam 45,98 hectares de áreas irregulares contra os 518,46 ha dos loteamentos regulares, o que representa $8,86 \%$ do percentual produzido nesta década. Sobre estas áreas foram feitos contratos de comodato e de compra e venda, com crédito direto com a companhia. Independente da forma estabelecida em contrato, com pagamento efetuado ou não, tais áreas pemanecem irregulares na situação da propriedade monopolizada ${ }^{47}$ pela COHAVEL ou pelo Município, compondo uma mercadoria informal da frente de expansão do capital, até o advento da Lei Federal $n^{\circ} 11.977 / 2009$, a qual realmente insere estas áreas no mercado imobiliário, ao gosto da frente pioneira.

\section{O desmanche da COHAVEL a partir da concepção de}

\section{financeirização}

A análise desta pesquisa sobre a promoção da irregularidade urbana na cidade de Cascavel não avança para além da década de 2000 devido a uma quebra na concepção de produção da irregularidade existente, bem como a presença da "regulação da exceção" nas novas legislações. Ou seja, a efetivação de um conjunto de hábitos, instituições e normas, que configuram um novo modo de regulação das relações sociais de produção capitalista,

\footnotetext{
${ }^{47}$ O monopólio do espaço é definido por Harvey (1980), como uma condição de existência do espaço institucionalizado, atrelado ao valor do solo urbano. Nessa visão, os de maior renda escolhem as melhores áreas da cidade, e os demais, pela ausência de escolhas, oportunizam a uma classe de proprietários de empreendimentos urbanos a obter a inclinação de uma clientela, a de menor poder aquisitivo, a se submeter as suas políticas monopolísticas (Harvey, 1980).
} 
diferente do vigente até então (Oliveira e Rizek, 2007). Este fenômeno de eliminação de todos os monopólios das empresas públicas que violem o direito de concorrência, é descrito por Dardot e Laval (2018) como recorrentes de uma política ordenadora, que descentraliza as ações de governo e conduz políticas vantajosas para empresas.

Tomando-se da metodologia de análise multiesclar apresenta-se uma leitura das relações das escalas Federal, Estadual e Local, envolvendo políticas e ações de desenvolvimento, na economia, nos produtos que vieram a influenciar o parcelamento do solo e a implantação de infraestrutura urbana. Estruturalmente, representam-se tais conjunturas na figura 7.

\begin{tabular}{|c|c|c|c|c|c|}
\hline década & \multicolumn{5}{|c|}{2000} \\
\hline NÍVEL & $\begin{array}{l}\text { política de } \\
\text { desenvolvimento }\end{array}$ & economia & produtos & \begin{tabular}{|l} 
legislação de \\
parcelamento
\end{tabular} & infraestrutura \\
\hline 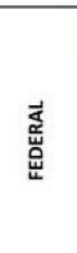 & $\begin{array}{l}\text { SOCIAL DEMOCRACIA, } \\
\text { SUBSIDIOS EM } \\
\text { PROGRAMAS } \\
\text { HABITACIONAISE } \\
\text { LINHA BRANCA } \\
\text { INDUSTRIAL (TRILOGIA } \\
\text { LOTEAMENTO/CASA } \\
\text { PROOPRIA/INDÚSTRIA DA } \\
\text { CONSTRUÇÃO) }\end{array}$ & FINANCEIRIZAÇÃO & AGROINDUSTRIAIS & $\begin{array}{l}\text { Lei } 6.766 / 1979 \mathrm{E} \\
\text { ESTATUTO DAS } \\
\text { CIDADES (Lei } \\
10.257 / 2001 \text { ) }\end{array}$ & $\begin{array}{l}\text { CONCESSÃOE E } \\
\text { PRIVATIZAÇĀOO }\end{array}$ \\
\hline NÍVEL & \begin{tabular}{|l|} 
politica de \\
desenvolvimento
\end{tabular} & economia & produtos & \begin{tabular}{|l|} 
produção de \\
parcelamentos
\end{tabular} & infraestrutura \\
\hline 宅 & \begin{tabular}{|l} 
PROGRAMAS \\
CONJUNTOS COM O \\
GOVERNO FEDERAL
\end{tabular} & \begin{tabular}{|l|} 
FINANCEIRIZAÇÃO \\
DEPENDENTE DE \\
RECURSO FEDERAL OU \\
INTERNACIONAL
\end{tabular} & AGROINDUSTRIAL & $\begin{array}{l}\text { PROGRAMA MINHA } \\
\text { CASA, MINHA VIDAE } \\
\text { REGULARIZAÇÃO } \\
\text { FUNDIÁRIA }\end{array}$ & $\begin{array}{l}\text { INTERLIGAČ̈ÄO } \\
\text { RODOVIÁRIA Á REDE } \\
\text { NACIONAL DE } \\
\text { CIDADES - Anel de } \\
\text { Integração }\end{array}$ \\
\hline & & & $\begin{array}{l}\text { NTE PIONEIRA NA } \\
\text { PERIFERIA }\end{array}$ & & \\
\hline NÍVEL & \begin{tabular}{|l|} 
política de \\
desenvolvimento
\end{tabular} & economia & produtos & \begin{tabular}{|l|} 
tipo de \\
parcelamento \\
resultante
\end{tabular} & infraestrutura \\
\hline छ্ & $\begin{array}{l}\text { PARCERIA COM O } \\
\text { GOVERNO FEDERAL, } \\
\text { FACILITADOR DA } \\
\text { GESTĀO DA PRODUÇ̄̃O } \\
\text { HABITACIONAL }\end{array}$ & $\begin{array}{l}\text { POLO REGIONAL DE } \\
\text { SERVIÇOS }\end{array}$ & $\begin{array}{l}\text { AGROINDÚSTRIA DE } \\
\text { ORIGEM E CONSUMO } \\
\text { ANIMAS, SERVIÇOS }\end{array}$ & \begin{tabular}{|l} 
PLANO DIRETOR \\
MUNICIPAL, COHAVEL \\
AGENTE PROMOTOR \\
DA IRREGULARIDADE \\
ALÉM DAS BARREIRAS \\
DAS BR'S
\end{tabular} & $\begin{array}{l}\text { PARCELAMENTOS } \\
\text { REGULARES COM } \\
\text { INFRAESTRUTURA DO } \\
\text { MCMV, IRREGULARES } \\
\text { COM } \\
\text { INFRAESTRUTURA } \\
\text { DEFICIENTE }\end{array}$ \\
\hline
\end{tabular}

Fig. 7 - Esquema multiescalar década de 2000 Fonte: Autoria própria

Para entender a mudança de paradigma da COHAVEL e o fim de sua ação na promoção da irregularidade urbana, baseia-se nas análises de Oliveira e Rizek (2007) sobre o desmonte das vigentes normas e legislações, visando o redirecionamento político-econômico para a financeirização. Este desmanche é sentido quando as discussões que permeiam o espaço 
conceitual sobre planejamento nos anos de 1980 se processam e começam a ser expressos efetivamente com a criação dos instrumentos do Estatuto da Cidade (Lei Federal $\mathrm{n}^{\circ}$ 10.257/2001). Suas possibilidades são aplicadas no Plano Diretor Municipal, localmente reformulado na Lei Municipal Complementar $n^{\circ}$ 28/2006 (Cascavel, 2006). As novas concepções são reforçadas com a regulamentação exposta na Lei Federal n ${ }^{\circ}$ 11.977/2009 Programa Minha Casa, Minha Vida - MCMV, juntamente com o instrumento de regularização fundiária. Com a lei e o instrumento, são passíveis de resolução os casos de regularização fundiária e, principalmente, a criação de novos loteamentos para a habitação de interesse social por meio de financiamento com a Caixa Econômica Federal, sendo o ente organizador o próprio Município. Ou seja, há a flexibilização legislativa para a maior intervenção do Estado no processo de desvalorização-revalorização, necessária ao capital, por meio de novos usos, edificações e infraestrutura. Também, mostra-se uma forte dependência de expansão do setor imobiliário de interesse social em relação ao poder público, em várias esferas, sem a anterior gestão das companhias habitacionais (Carlos et al., 2015).

A nova redistribuição de tarefas pode ser verificada localmente quando, no Plano Municipal de Habitação - PMH de Cascavel (2012), em seus estudos desenvolvidos no final do ano de 2010, aponta que a COHAVEL, antes executora da política habitacional local, teve parte de suas atribuições de planejamento de projetos e execução de obras com fins habitacionais assumidas pela SEPLAN - Secretaria Municipal de Planejamento. A secretaria cria um setor no ano de 2009 para assumir a gestão dos empreendimentos habitacionais e a seleção dos possíveis mutuários, na faixa de renda familiar mensal até $\mathrm{R} \$ 1.600,00$.

Esse novo consenso no campo da política habitacional tem seu início na década de 1990, quando o Banco Mundial defende o decréscimo de orçamento direcionado para os órgãos públicos de habitação, com baixa capacidade de retorno de investimentos, e um engajamento redirecionado de orçamento para setores de mais alta renda, possibilitando a ação de intermediários financeiros, que se consolida ao longo da década de 2000 (Carlos et al., 2015). Os governos abandonam o papel de produtor habitacional para adotar o papel de facilitador da gestão do setor habitacional como um todo (Rolnik, 2015). Verifica-se o "desmanche" dos centros de decisões, das relações entre Estado e sociedade, da ordem 
jurírica-política, que torna irrelevante as associações públicas e estatais, em favor das relações financeiras de acumulação de capital (Oliveira e Rizek, 2007).

A COHAVEL tem, a partir de então, somente o papel de agente regulador, como parceiro da secretaria gestora, havendo seu sucateamento técnico e de funções durante a década de 2000, com um período de reavivamento nas funções de parcelamento e habitacional, inclusive de irregularidades, dentre os anos de 2005-2008. Chegou-se até a cogitar a extinção da empresa pública municipal no início da segunda gestão do prefeito Edgar Bueno (2009-2012), ação que não aconteceu até o presente momento, permanecendo sucateada (Cascavel, 2012).

Inexistindo no Município uma Política Habitacional consistente, ao longo de sua existência a companhia dedicou esforços na reforma dos próprios municipais desviando-se de sua finalidade primeira. A falta de diretriz para a ação, a falta de clareza nas atribuições, além de falhas administrativas e processuais, determinou que a grande maioria dos empreendimentos iniciados pela COHAVEL, hoje se encontrem irregulares. As irregularidades constatadas consistem falta de conclusão nos processos e não atendimento à legislação urbanística (Cascavel, 2012: 79).

Torna-se sensível, localmente, a mudança de estratégia de gestão sobre a produção da irregularidade, no sentido de que, a COHAVEL, antes responsável pela política inconfessa, ou não declarada, de implantação de loteamentos na periferia, atropelando burocracias a fim de seguir o propósito de colocá-los na frente de expansão capitalista, com suas estruturas na margem da legalidade para o barateamento das aquisições, mas prontos para serem incorporados à cidade, são substituídos, efetivamente pela concepção da frente pioneira do capital. Isto é, são incorporados às leis regulares de mercado, na trilogia "loteamento/casa própria/indústria da construção", ainda organizada pelo Município, mas avalizada pelos órgãos federais, em uma estratégia habitacional nacional (Mautner, 2010). A racionalização ora instaurada sistematiza uma nova lógica na forma de encurtar caminhos entre as empreiteiras e os recursos financeiros dos empreendimentos habitacionais do programa Federal (Oliveira e Rizek, 2007).

Localmente, ao final da década de 2000 não há mais notícias de assentamentos ou loteamentos irregulares públicos envolvendo a COHAVEL como promotora. 


\section{Considerações finais}

O tema sobre a irregularidade urbana apresenta-se atual quando não se atém somente sobre questões atreladas às práticas de corrupção, patrimonialismo e clientelesmo, mas, junto a estas, expõe o caráter econômico da informalidade urbana, discutindo o preço da terra e a expansão do capitalismo, temas já fundamentados por Francisco de Oliveira (2013) e Martins (1996) no âmbito brasileiro. Esse assunto é geralmente debatido por geógrafos, sociólogos e economistas que teorizam a cidade. E, também, por arquitetos e urbanistas com pesquisas em grandes centros, que ultrapassam o viés morfológico, destacando-se os trabalhos de Rolnik (2015) e Mautner (2010). Contudo, a problemática encontra uma lacuna sobre os centros urbanos menores, com dinâmicas econômicas menos intensas, e, por isso mesmo, mais visíveis, mas igualmente complexas ao dos grandes centros urbanos. Justificase, portanto, entender as ações públicas habitacionais na periferia da expansão do capital, em um município de porte médio, de relevância para o desenvolvimento estadual, atrelado a políticas municipais e aos processos da produção da cidade capitalista. Portanto, o artigo evidencia, em diferentes escalas, numa abordagem multiescalar, o estabelecimento dos interesses da frente pioneira na mercantilização da terra, primeiramente na fronteira agrícola e depois na área urbana de Cascavel.

Como mediadora imobiliária da frente de expansão do capital, o papel da COHAVEL, a partir de sua estruturação na primeira metade da década de 1990, fica evidente em dois aspectos. Primeiro, durante o processo de implantação das áreas irregulares, teve a incumbência de fomentar o comércio, empregos e trabalho informal, através da construção civil. Depois, na ocupação, com um monopólio de áreas irregulares, sem dar a garantia de propriedade, atendeu uma população de baixa renda, excluída do mercado formal das áreas urbanizadas, para manutenção dos baixos custos da reprodução da força de trabalho e, consequentemente baixos salários. Como resultado, produziu a soma de 1669 lotes, num total de 65,68 ha, entre meados da década de 1990 e a 2000.

O seu papel no mercado imobiliário informal, na produção de novas áreas irregulares no fomento ao trabalho de baixo custo, tornou-se desnecessário a partir do estabelecimento da concepção de financeirização também nas áreas periféricas da cidade, ao final dos anos 
2000, concomitante ao progressivo fortalecimento de Cascavel como um polo regional de serviços.

Anuncia-se o desmanche da COHAVEL, mas a gestão da irregularidade urbana não acaba. Atua em pequenas ações remediadoras das desigualdades, administrando a exceção, na qual se pode enquadrar o instrumento da regularização fundiária urbana (Oliveira, 2003; Carlos et al., 2015). As funções da COHAVEL foram absorvidas pela secretaria de planejamento e o seu papel na política habitacional de Cascavel foi reduzido ao de coadjuvante, ao reformular contratos e rever parcelas das dívidas dos terrenos vendidos anteriormente e agora em processo de regularização. Paulatinamente, todas as suas áreas de monopólio serão integradas ao mercado formal, conforme as definições de urgência e racionalidade do mesmo. Estabelece-se a financeirização na periferia retroalimentada pela fronteira de expansão do capital que se encontra em outras fronteiras.

\section{Referências}

ANDRADE, T.A.; SERRA,R.V. (Orgs.). Cidades médias brasileiras. Rio de Janeiro: IPEA, 2001

BARBIERI, A.F., 2007. Mobilidade populacional, meio ambiente e uso da terra em áreas de fronteira: uma abordagem multiescalar. In: Rev. Bras. Estud. Popul., São Paulo, vol.24, n.2, 225-246, jul/dez. 2007. Acesso em Julho 2016. Disponível em: http://www.scielo.br/pdf/rbepop/v24n2/03.pdf

BELUSSO, D. A formação das cooperativas agrícolas e a expansão da avicultura de abate no oeste paranaense (1970-2010). In: BOSI, A.P. (Org.). 2014. Trabalho e trabalhadores no processo de industrialização recente no oeste do Paraná (1970-2010): estudos sobre a cadeia avícola: Jundiaí-SC: Paco Editorial, 2014.

CARLOS, A.F. Da organização à produção do espaço no movimento do pensamento geográfico. In: CARLOS, A.F.; SOUZA, M.L.; SPOSITO, M.E.B. (Orgs). 2014. A produção do espaço urbano: agentes e processos, escalas e desafios: 1 ed. São Paulo-SP: Contexto, 2014, 53-73.

CARLOS, A.F. O espaço urbano: novos escritos sobre a cidade. São Paulo-SP: FFLCH, 2007

CARLOS, A.F.; VOLOCHKO, D.; ALVAREZ, I.P. (Orgs.) A cidade como negócio. São Paulo-SP: Contexto, 2015.

CASCAVEL. 2012. Lei $n^{0}$ 6.063, de 18 de junho de 2012. Estabelece a política habitacional no município de Cascavel, instituída pelo Plano Municipal de Habitação e dá outras providências. Órgão oficial eletrônico [do] Município de Cascavel. Edição Ordinária, n 596, Ano IV, Caderno 1, Atos do Poder Executivo, p.1-143, 28 jun. 2012. Acesso em Maio, 2019. Disponível em: http://www.cascavel.pr.gov.br/anexos/2012062716554101.pdf.

CASTELLS, M. A questão urbana. São Paulo: Paz e Terra, 2009

CLICHEVSKY, N. Algunas reflexiones sobre informalidad y regularización del suelo urbano. Bitácora Urbano Territorial. Bogotá: Universidad Nacional de Colombia, 1, 14, 63-88, junio 2009. Acesso em Outubro, 2019. Disponível em: https://revistas.unal.edu.co/index.php/bitacora/article/view/18508/pdf 36

CORRÊA, R.L. O espaço urbano. 3 ed. São Paulo-SP: Ática, 2005.

DARDOT, P.;LAVAL, C. A nova razão do mundo: ensaio sobre a sociedade neoliberal. 1 ed. 2 reim. São Paulo-SP: Boitempo (Estado de Sítio), 2018. 
GONZÁLEZ-PÉREZ, J.M. Urban inequality: the city after the 2007 crisis. Urban Sci. 2018,2, 1-5, Jul. 2018. Visto em Outubro, 2019. Disponível em: https://www.mdpi.com/2413-8851/2/3/62

GOTTDIENER, M. A produção social do espaço urbano. 2 ed. 1 reimpr. São Paulo-SP: EdUsp, 2010.

HARVEY, D. A justiça social e a cidade. São Paulo-SP: Hucitec, 1980

IBGE. 2018. População. Visto em Maio, 2019. Disponível em: https://cidades.ibge.gov.br/brasil/pr/cascavel/panorama

LEFEBVRE, H. O direito à cidade. São Paulo-SP: Centauro, 2011.

MARIANO, M. A capital do oeste: um estudo das transformações e (re) significações da ocupação urbana em Cascavel-PR (1976-2010). Dissertação de Mestrado em História. Universidade do Estado de Santa Catarina, UDESC, Florianópolis-SC, 2012.

MARTINS, J.S. O tempo da fronteira: retorno à controvérsia sobre o tempo histórico da frente de expansão e da frente pioneira. Tempo Social; Rev. Sociologia. São Paulo-SP: USP, 8, 25-70, 1996. Acesso em Julho, 2016. Disponível em: http://www.revistas.usp.br/ts/article/view/86141

MARX, K. O capital: Crítica da economia política: O processo de produção do capital. Tradução Rubens Enderle, 2013. Acesso em Outubro, $2019 . \quad$ Disponível https://edisciplinas.usp.br/pluginfile.php/2547757/mod resource/content/1/MARX\%2C\%20Karl.\%200\%20Ca pital.\%20vol\%20l.\%20Boitempo..pdf

MAUTNER, Y. A periferia como fronteira da expansão do capital. In: DÉAK, C.; SCHIEFFER, S.R. (Orgs.). O processo de urbanização no Brasil: São Paulo-SP: Edusp, 2010, pp. 245-259

MUNICÍPIO DE CASCAVEL, 2014. Detalhe dos mapas de zoneamento e implantação, loteamentos: Quebec e Melissa. In: Geoportal. Acesso em Março, 2014. Disponível em: http://geocascavel.cascavel.pr.gov.br/geoview/index.ctm

MYSKIW, A.M. Colonos, posseiros, grileiros: conflitos de terra no Oeste paranaense (1961-66). Dissertação de Mestrado em História. Universidade Federal Fluminense, UFF, Niterói-RJ, 2002

OLIVEIRA, D. Urbanização e industrialização no Paraná. Coleção história do Paraná. Curitiba-PR: SEED, 2002.

OLIVEIRA, F. Crítica à razão dualista: O ornitorrinco. 1ed., 4 reimpr. São Paulo-SP: Boitempo, 2013

OLIVEIRA, F.; RIZEK, C.S. (Orgs). A era da indeterminação. São Paulo-SP: Boitempo, 2007.

PIAIA, V. Terra sangue e ambição: a gênese de Cascavel. Cascavel-PR: ABEU, 2013.

REOLON, C.A. A aglomeração urbana da soja: Cascavel e Toledo no contexto da metropolização na Mesorregião Oeste Paranaense. Dissertação de Mestrado em Desenvolvimento Regional e Agronegócio. Universidade Estadual do Oeste do Paraná, Unioeste, Toledo-PR, 2007.

ROLNIK, R. Guerra dos lugares: a colonização da terra e da moradia na era das finanças. São Paulo-SP: Boitempo, 2015.

SAULE JUNIOR, N. A proteção jurídica da moradia nos assentamentos irregulares. Porto Alegre-RS: Sergio Antonio Fabris Editor, 2004.

SMOLKA, M.O. Regularização da ocupação do solo urbano: o problema que é parte da solução, a solução que é parte do problema. In: FERNANDES, E.; ALFONSIN, B. (Orgs). A lei e a ilegalidade na produção do espaço urbano: Belo Horizonte-MG: Ed. Del Rey, 2003, pp.255-291.

SOARES et al. Localização do Município na mesorregião Oeste do Paraná, com rodovia BR-35, 1990. In: SOARES, K.A.S.; CORDOVIL, F.S.C.; PAVIANI, M.T. 2018. Da concepção à entrega do projeto de urbanização de assentamento precário: relato e análise do caso do Loteamento Melissa, Cascavel PR: III URBFAVELAS Seminário Nacional de Urbanização de Favelas, Salvador-BA: UCSal, 2018, p. 2. ISBN: 978-85-88480-49-0

SOARES, K.A.S. Produção da irregularidade urbana: gestão, agentes, processos e práticas espaciais no território de Cascavel/PR. Dissertação de Mestrado em Arquitetura e Urbanismo. Universidade Estadual de Maringá, UEM, Maringá, 2016.

SPERANÇA, A.A. Cascavel: a história. Cascavel-PR: Editora Gráfica Positiva, 2007. 
TAVOLARI, B. Direito à cidade: uma trajetória conceitual. Novos Estudos CEBRAP. São Paulo-SP: CEBRAP, 2016. Acesso em Outubro 2019. Disponível em: http://www.scielo.br/pdf/nec/v35n1/1980-5403-nec-35-01-93.pdf

TELLES, V.S. A cidade nas fronteiras do legal e ilegal. Coleção Sociedade \& Cultura. Belo Horizonte-MG: Ed. Argvmentvm, 2010.

TSCHÁ, O.C.P.; RIPPEL, R.; LIMA, J.F. Transformação produtiva, urbanização, industrialização e migração no Oeste do Paraná. In: XIX Encontro Nacional de estudos Populacionais: População, Governança e Bem-estar São Pedro-SP: Abep - Associação Brasileira de Estudos Populacionais. 1-18, Novembro 2014. Acesso em Fevereiro, 2015. Disponível em: http://www.abep.org.br/publicacoes/index.php/anais/article/viewFile/2285/2239 